\title{
Determination of Fibernolytic Enzyme Activities of White Rot Fungi Isolated from Oil Palm Fronds
}

\author{
Azmi MAB ${ }^{1}$, Alias $\mathrm{S}^{1}$, Azmi AFM ${ }^{1}$, Ghani AAA ${ }^{1}$, Shahudin $\mathrm{MS}^{1}$, Goh $\mathrm{YM}^{1}$, Noordin $\mathrm{MM}^{1}$, \\ Yusof $\mathrm{MT}^{2}$, Zunita $\mathrm{Z}^{1}$, Hassim $\mathrm{HA}^{1}$ \\ 'Faculty of Veterinary Medicine, Universiti Putra Malaysia, Serdang 43400, Selangor, Malaysia \\ ${ }^{2}$ Faculty of Biotechnology and Biomolecular Sciences, Universiti Putra Malaysia, Serdang 43400, Selangor, Malaysia \\ E-mail: haslizaabu@upm.edu.my
}

(received 10-05-2016; revised 26-06-2016; accepted 16-05-2016)

\begin{abstract}
ABSTRAK
Azmi MAB, Alias S, Azmi AFM, Ghani AAA, Shahudin MS, Goh YM, Noordin MM, Yusof MT, Zunita Z, Hassim HA. 2016. Penentuan aktivitas enzim pengurai serat kapang lapuk putih yang diisolasi dari pelepah sawit. JITV 21(2): 144-150. DOI: http://dx.doi.org/10.14334/jitv.v21i2.1362

Pelepah sawit (OPF) banyak digunakan sebagai sumber serat untuk hewan ternak. Namun, potensi keseluruhan OPF sebagai pakan ternak dibatasi oleh kadar lignin yang tinggi yang menghambat aktivitas rumen mikroba untuk menguraikan selulosa dan hemiselulosa. Fungi lapuk putih (WRF) adalah kelompok fungi filum basidiomisetes, umumnya ditemukan di kayu busuk, dan mampu untuk mendegradasi lignin. Percobaan ini bertujuan untuk mengidentifikasi filum fungi yang terbaik berdasarkan aktivitas rasio enzim pengurai lignin terhadap selulase dan hemiselulase. Dalam percobaan ini, sebelas isolat fungi didapatkan dari pelepah sawit busuk dengan label WR1, WR 2, WR3, WR4, WR5, WR6, WR7, WR8, WR9, WR10 dan WR11. Aktivitas enzim fungi pengurai serat yang mencakup lakase, peroksidase mangan dan lignin peroksidase, aviselase, carboksimetilselulase dan xilanase dianalisis dari fermentasi substrat padat. Data menunjukkan bahwa 5 fungi yang merupakan WR1, WR2, WR4, WR7 dan WR10 menghasilkan rasio tertinggi enzim pengurai lignin terhadap pengurai selulosa dan hemiselulosa. Sambungan apit fungi tersebut kemudian diamati di bawah mikroskop untuk menentukan filum. Keberadaan sambungan apit menunjukkan fungi termasuk filum Basidiomisetes.
\end{abstract}

Kata Kunci: Daun Kelapa Sawit, White Rot Fungi, Lignin, Enzim

\section{ABSTRACT}

Azmi MAB, Alias S, Azmi AFM, Ghani AAA, Shahudin MS, Goh YM, Noordin MM, Yusof MT, Zunita Z, Hassim HA. 2016. Determination of fibernolytic enzyme activities of white rot fungi isolated from oil palm fronds. JITV 21(2): 144-150. DOI: http://dx.doi.org/10.14334/jitv.v21i2.1362

Oil palm fronds (OPF) is widely used as the source of roughage for the farm animals. However, the full potential of OPF as animal feed is limited by their high lignin content which limits the rumen microbe's access to the cellulose and hemicellulose. White rot fungi (WRF) are a group of fungi belonging to basidiomycete phylum and are commonly found in decaying woody plant. They possess the ability to degrade lignin. This experiment aims to identify the phylum of the best lignin decaying fungi based on their ratio ligninolytic to cellulytic and hemicellulytic activities. In this experiment, 11 fungi species were isolated from decaying oil palm fronds. They are labelled as WR1, WR 2, WR3, WR4, WR5, WR6, WR7, WR8, WR9, WR10 and WR11. Their fibernolytic enzyme activities which include laccase, manganese peroxidase, lignin peroxidase, avicelase, carboxylmethylcellulase and xylanase are analysed from solid state fermentation method. It was found that 5 fungi species which are the WR1, WR2, WR4, WR7 and WR10 produced the highest ratio of lignin degrading enzyme to cellulose and hemicellulose degrading enzyme. The fungi are then analysed under microscope to determine the phylum of the fungi. From the observation, the fungi are identified to belong to the phylum of basidiomycetes due to presence of clamp connection.

Key Words: Oil Palm Fronds, White Rot Fungi, Lignin, Enzyme

\section{INTRODUCTION}

Malaysia is one of the largest palm oil producers. In 2008, Malaysia produced 17.7 million tonnes of palm oil based on 4,500,000 hectares used for the plantation of oil palm making it the second largest producer of palm oil in the world behind Indonesia (Abdullah \&
Sulaiman 2013). The large plantation of oil palm results in the large production of oil palm by-products. One of the main by-product of the palm oil plantation is the oil palm fronds. The oil palm fronds are obtained during pruning, felling and harvesting processes. Approximately 30,000,000 tonnes of oil palm fronds are produced in a year (Zahari \& Farid 2011). Oil palm 
fronds (OPF) has been widely used as animal feed in its various forms, those were freshly chopped, silage and pellets or cubes (Zahari \& Farid 2011). Apart from that, the oil palm fronds are commonly used as a source of roughage. The usage of OPF as animal feed is limited due to its high lignin content and low protein content (Wan-Rosli et al. 2007). According to Zhang \& Zhao (2010), the lignocellulosic biomass is made up from polymeric carbohydrates, which consist of cellulose, hemicellulose, and lignin. The digestibility of cellulose present in lignocellulosic biomass, such as OPF, is impeded by various physiochemical, structural, and compositional factors (Binod et al. 2012).The existence of hemicellulose and lignin in lignobiomass is aimed to impart strength to plant cell walls and protect cellulose from enzymatic degradation.

The white rot fungi consist of mostly basidiomycetes are efficient degrader of lignin (Smith $\&$ Thurnston 1997). The fungi are an excellent degrader of lignin via the excretion of extracellular enzymes. The enzymes are laccase, manganese peroxidase $(\mathrm{MnP})$, and lignin peroxidase (Hassim et al. 2012). The usage of these enzymes to treat the oil palm fronds is believed to increase the efficiency of oil palm fronds by improving ruminal degradability.

The objective of this study is to determine the enzyme activity of white rot fungi isolated from decaying oil palm fronds and selecting 5 fungi species that are able to increase the degradability of OPF as animal feed. The fungi selected are then identified up to phylum level.

\section{MATERIALS AND METHODS}

\section{Isolation and cultivation of white rot fungi}

Sample of fungi ware isolated from rotten oil palm fronds collected from oil palm plantation located in Taman Pertanian Universiti, Universiti Putra Malaysia. The fungi were cultured on PDA agar plate at $30^{\circ} \mathrm{C}$ for 7 days. Small portion of each fungus colonies were then transferred into fresh plate and cultured for another 7 days at $30^{\circ} \mathrm{C}$. The process was repeated until pure cultures were obtained. Plugs of $7 \mathrm{~mm}$ diameter from the purified cultures were then cultured on PDA agar plate for 5 days and the growth of the mycelia were observed (Namoolnoy et al. 2011).

\section{Oil palm fronds fermentation}

Solid state fermentation was carried out in $250-\mathrm{mL}$ Erlenmeyer flask. Oil palm fronds collected from Ladang Kelapa Sawit, Taman Pertanian Universiti, Universiti Putra Malaysia, was divided and grinded into smaller pieces using warring blender. Each flask contains $15 \mathrm{~g}$ of grinded oil palm fronds. Each flask was added with $45 \mathrm{ml}$ of Deionized water and $22.5 \mathrm{mg}$ of glucose. The flasks were then autoclaved at $121^{\circ} \mathrm{C}$ for 15 minutes. Three $10 \mathrm{~mm}$ diameter plugs from each isolated fungus were added to the sterile flask as inoculum. The flask was then covered with cotton ball and sealed with aluminium foil and incubated at room temperature $\left(37^{\circ} \mathrm{C}\right)$. The enzyme was extracted using $150 \mathrm{ml}$ of deionized water added to each flask and placed inside rotary shaker for 3 hours. The mixture was then filtered. The filtrate was then centrifuged at $12,000 \mathrm{~g}$ at $4^{\circ} \mathrm{C}$ and the supernatant was collected. The step sampling was repeated for 15 days, 30 days and 45 days fermentation for each isolated fungal species (Dinis et al. 2009).

\section{Enzyme activity determination}

\section{Lignolytic enzyme}

For screening of Laccase (EC 1.10.3.2) activity, a citrate-phosphate buffer was prepared by adding $1.921 \mathrm{~g}$ to $100 \mathrm{ml}$ of distilled water. The solution was labelled as solution A. Then, $3.5814 \mathrm{~g}$ of $\mathrm{Na}_{2} \mathrm{HPO}_{4}$ was added into $100 \mathrm{ml}$ of distilled water. The solution was labelled as solution B. $50 \mathrm{ml}$ of solution A was added to $50 \mathrm{ml}$ of solution $\mathrm{B}$ and the $\mathrm{pH}$ is adjusted to $\mathrm{pH} 4.0$. For the substrate, ABTS solution was prepared by adding 164.6 $\mathrm{mg}$ of ABTS to $10 \mathrm{ml}$ of distilled water. The ABTS solution was then transferred to an Eppendorf tube. The mixture tube was prepared by adding $1300 \mu \mathrm{l}$ citratephosphate buffer, $100 \mu \mathrm{l}$ ABTS and $100 \mu \mathrm{l}$ enzyme extract. For the blank, $1300 \mu$ l citrate-phosphate buffer was mixed with $100 \mu \mathrm{l}$ ABTS. The mixtures were then covered with parafilm and were read at absorbance of $420 \mathrm{~nm}$ against blank (Dinis et al. 2009).

For screening of Lignin Peroxidase (EC 1.11.1.14; $\mathrm{LiP}$ ), acid tartrate buffer was prepared by adding 3.752 $\mathrm{g}$ of the acid in $250 \mathrm{ml}$ distilled water. The $\mathrm{pH}$ was then adjusted to 3.0 using acid/sodium tartrate buffer. The buffer was then kept in $4^{\circ} \mathrm{C}$. The substrate was prepared by adding $0.105 \mathrm{ml}$ veratryl alcohol with $25 \mathrm{ml}$ distilled water. The solution was then store in $4^{\circ} \mathrm{C}$ in Eppendorf tubes. Hydrogen peroxide, $\mathrm{H}_{2} \mathrm{O}_{2}$ was then prepared according to manufacturer specification. The mixture tube was prepared by adding $2550 \mu \mathrm{l}$ of acid tartrate buffer, $200 \mu \mathrm{l}$ veratryl alcohol, $30 \mu \mathrm{H}_{2} \mathrm{O}_{2}$, and $200 \mu \mathrm{l}$ enzyme extract. For the blank, the mixture solution was prepared with $2550 \mu \mathrm{l}$ acid tartrate buffer, $200 \mu \mathrm{l}$ veratryl alcohol and $30 \mu \mathrm{H}_{2} \mathrm{O}_{2}$. The tubes was read at absorbance of $238 \mathrm{~nm}$ against blank (Dinis et al. 2009).

For screening of Manganese Peroxidase (EC 1.11.1.13; MnP), tartrate buffer was prepared by adding $5.752 \mathrm{~g}$ sodium tartrate with $250 \mathrm{ml}$ distilled water. The $\mathrm{pH}$ was adjusted to 5.0 by adding acid/sodium tartrate buffer. The solution was kept at $4{ }^{\circ} \mathrm{C}$. For the substrate, $0.25353 \mathrm{~g}$ of Manganese sulphate, $\mathrm{MnSO}_{4}$ was mixed 
with $50 \mathrm{ml}$ of distilled water. It was then stored in $4^{\circ} \mathrm{C}$. $\mathrm{H}_{2} \mathrm{O}_{2}$ was prepared according to manufacturer's standard. The mixture tube was prepared by adding $2550 \mu \mathrm{l}$ sodium tartrate buffer, $200 \mu \mathrm{l}$ manganese sulphate, $30 \mu \mathrm{l}$ hydrogen peroxide, $\mathrm{H}_{2} \mathrm{O}_{2}$, and $200 \mu \mathrm{l}$ enzyme extract. For the blank, the mixture is consist of $2550 \mu \mathrm{l}$ sodium tartrate buffer, $200 \mu \mathrm{l}$ manganese sulphate, and $30 \mu \mathrm{l}$ hydrogen peroxide, $\mathrm{H}_{2} \mathrm{O}_{2}$. The absorbance was then read at $238 \mathrm{~nm}$ (Dinis et al. 2009).

\section{Cellulolytic enzyme}

For screening of Carboxylmethyl cellulase (CMcase) enzyme, the substrate was prepared by adding $1 \mathrm{~g}$ of carboxymethylcellulose to $100 \mathrm{ml}$ distilled water. The solution was then stirred until it became homogeneous. The buffer used in this experiment is $0.1 \mathrm{M}$ citrate buffer at $\mathrm{pH} 4.8$. The mixture is prepared by adding $1 \mathrm{ml}$ of citrate buffer, 0.5 $\mathrm{ml}$ enzyme extract, and $0.5 \mathrm{ml}$ carboxylmethyl cellulose. The tubes were then incubated at $39^{\circ} \mathrm{C}$ for 20 minutes. The reaction was stopped by adding $3 \mathrm{ml}$ of dinitrosalicylic acid, DNS to each tube. The control tube was prepared by adding $1 \mathrm{ml}$ of citrate buffer and $0.5 \mathrm{ml}$ carboxylmethylcellulose, and $3 \mathrm{ml}$ of DNS was added to all control tube. The reaction and control tubes were placed in boiling water bath for 10 minutes and were then read at absorbance of $575 \mathrm{~nm}$. Calibration curve was made by plotting absorbance against glucose concentration. The glucose solution was prepared by dissolving $0.1 \mathrm{~g}$ of glucose in $100 \mathrm{ml}$ of distilled water (Dinis et al. 2009).

For screening of Avicelase enzyme, the substrate was prepared by dissolving $1 \mathrm{~g}$ of Avicel microcrystalline in $100 \mathrm{ml}$ of distilled water. The solution was then stirred until it became homogeneous. In this experiment, the buffer used was $0.1 \mathrm{M}$ citrate buffer at $\mathrm{pH}$ 4.8. The mixture was prepared by adding 1 $\mathrm{ml}$ citrate buffer, $0.5 \mathrm{ml}$ of enzyme extract and $0.5 \mathrm{ml}$ Avicel cellulose microcrystalline solution. The tubes were then incubated at $39^{\circ} \mathrm{C}$ for 20 minutes. The reaction was stopped by adding $3 \mathrm{ml}$ DNS solution to each test tube. Substrate control tube was prepared by adding $0.5 \mathrm{ml}$ substrate with $1.5 \mathrm{ml}$ citrate buffer. The enzyme control tube was prepared by mixing $0.5 \mathrm{ml}$ enzyme extract with $1.5 \mathrm{ml}$ citrate buffer. $3 \mathrm{ml}$ of DNS was added to all control tubes. The reaction and control tubes were then placed inside boiling water bath for 10 minutes. The absorbance was then read at $575 \mathrm{~nm}$ against blank. Standard calibration curve was plotted against glucose concentration. The $0.1 \%$ glucose standard was prepared by dissolving $0.1 \mathrm{~g}$ glucose in $100 \mathrm{ml}$ distilled water (Dinis et al. 2009).

\section{Hemicellulolytic enzyme}

Xylan was prepared by combining $0.25 \mathrm{~g}$ of xylan with $100 \mathrm{ml}$ of distilled water. The mixture was then warmed at $70^{\circ} \mathrm{C}$ with continuous shaking. The assay mixture was prepared by adding $0.1 \mathrm{M}$ of citrate buffer at $\mathrm{pH} 4.8,0.5 \mathrm{ml}$ enzyme extract and $0.5 \mathrm{ml}$ of $0.25 \%$ xylan solution. The tubes were incubated at $39^{\circ} \mathrm{C}$ for 30 minutes. The reaction was stopped by adding $3 \mathrm{ml}$ of DNS to each reaction tube. The control tube for substrate was prepared by adding $0.5 \mathrm{ml} 0.25 \%$ xylan with $1.5 \mathrm{ml}$ citrate buffer. For the enzyme control tube, $0.5 \mathrm{ml}$ of sample was mixed with $1.5 \mathrm{ml}$ citrate buffer. 3 $\mathrm{ml}$ of DNS was added to all control tubes. All tubes were placed in boiling water bath for 10 minutes and absorbance was read at $575 \mathrm{~nm}$ against blank. Calibration curve was prepared by plotting absorbance against xylose concentration. The standard xylose solution was prepared by dissolving $0.1 \mathrm{~g}$ of xylose in $100 \mathrm{ml}$ of distilled water (Dinis et al. 2009).

\section{Fungi staining and phylum identification}

Some fungi that showed the most desirable enzyme activity were selected. The selected fungi were then cultured on PDA agar plates. The plates were incubated at room temperature for 7 days. The grown fungi were stained with methylene blue and observed under light microscope. The presence of clamp connection in the hyphae were observed (Toda et al. 2012).

\section{RESULTS AND DISCUSSION}

All fungi recorded positive activity for the enzyme tested. In general, the fungi showed the highest lignolytic enzyme activity compared to other enzyme tested. All fungi recorded highest laccase activity on day 45 with exception of WR3. For the lignolytic enzyme activity which is presented in Figure 1, lignin peroxidase activity of fungi WR2 and WR6 recorded highest activity on day 15. WR1, WR4 and WR7 recorded highest activity on day 30 . The rest of the fungi recorded the highest activity on day 45. For Manganese Peroxidase enzyme activity, WR2, WR4, WR5, WR7, and WR9 recorded the highest activity on day 15. Fungi WR1, WR6 and WR 11 recorded the highest Manganese Peroxidase on day 30. The rest of the fungi have the highest manganese peroxidase activity recorded on day 45 . 

Laccase

0.15

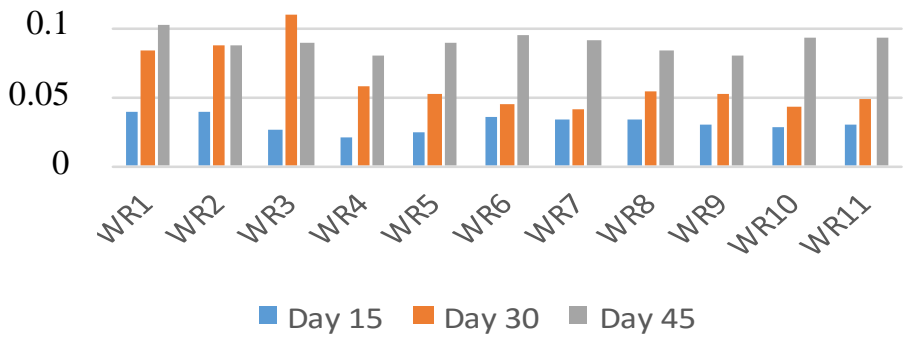
Lignin Peroxidase

2

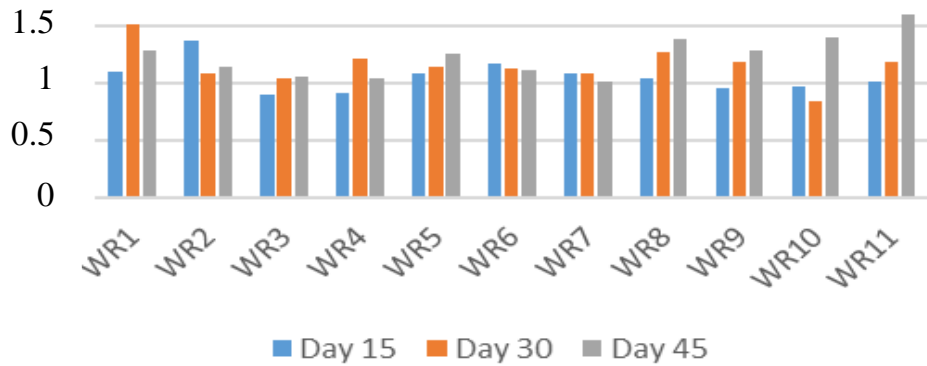
Manganese Peroxidase

0.5

0.4

0.3

0.2

0.1

0

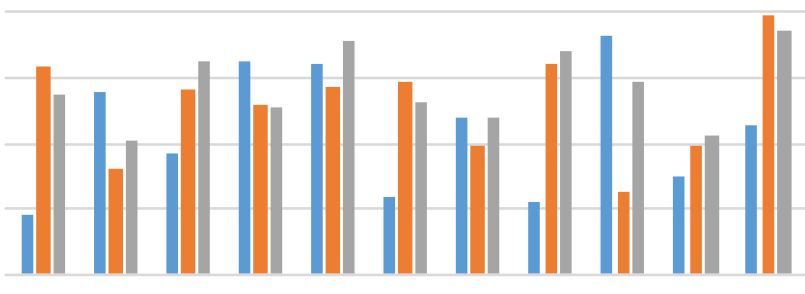

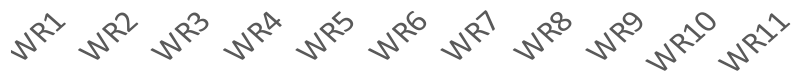

Day 15 Day 30 Day 45

Figure 1. Activity of lignolytic enzymes: Laccase (a), lignin peroxidase (b), and manganese peroxidase (c) of isolated fungi after fermentation at oil palm fronds at 15, 30, and 45 days. 


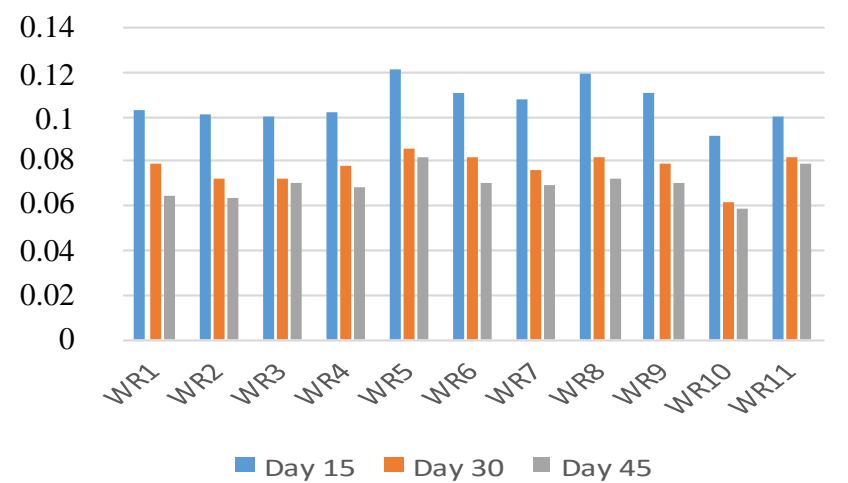

\section{Carboxylmethylcellulase}

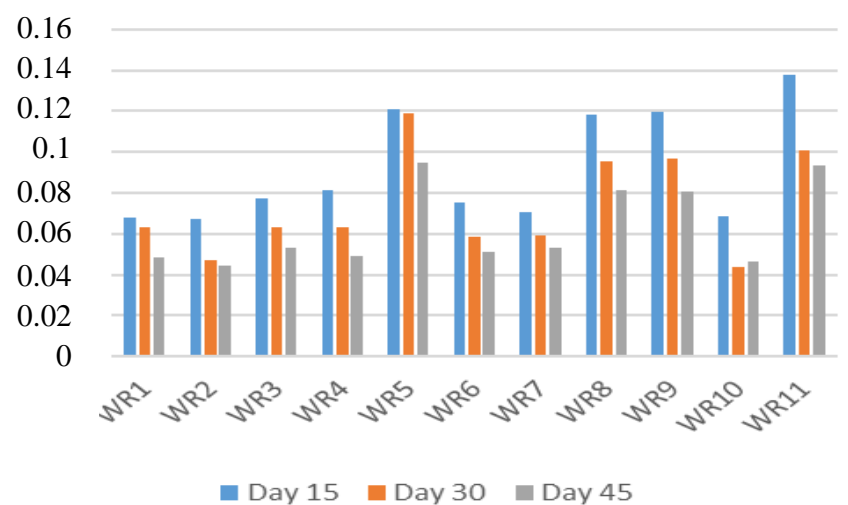

Figure 2. Activity of cellulolytic enzymes: Avicelase (a) and carboxylmethylcellulase (b) after fermentation at oil palm fronds at 15, 30 , and 45 days.

The lignolytic enzyme activity is vital as it removes the lignin content which limits the access of rumen microbe toward the cellulose and hemicellulose. The presence of lignin also presents a problem as it is one of the main components of lignocellulosic biomass. The lignocellulosic biomass not only limits the physical access of rumen microbe toward the cellulose and hemicellulose, it also effectively inhibit the cellulose and hemicellulose from the reaction site via adsorption (Gusakov et al. 1985). Hence, it is important for the lignolytic enzyme to be high in selection criteria to increase the degradability of OPF.

In cellulolytic enzyme activity which is presented in Figure 2, for avicelase enzyme, the activity is highest at day 15 for all fungi followed by day 30 and 45 respectively. Carboxylmethylcellulase activity showed that WR5, WR 8, WR9, and WR11 had the highest average activity for all time period.
From the results, cellulose degrading enzymes show higher readings at 15 days and gradually decrease at 30 and 45 days. Alam et al. (2005) suggested that this is due to formation of aromatic water-soluble products from delignification process which suppress the cellulolytic action of the enzymes.

All fungi show low enzyme activity for xylanase with the exception of WR 5, WR8, WR9, and WR 11. However, the enzyme activity remains relatively constant for 15, 30 and 45 days observation with slight fluctuation. The activity of xylanase is the highest at 30 days fermentation period due to longer of fermentation time. However, nutrient depletion by the action of the fungi causes the xylanase activity to drop in 45 days fermentation time (Haq et al. 2002).

WR1, WR2 WR4, WR7, and WR10 have the optimal enzyme activity for pre-treating the OPF. The selection is based on the highest average recorded of lignin degrading enzyme as the lignin limits the 
rumen's microbe accessibility to the cellulose and hemicellulose (Moore \& Jung 2001; Dias et al. 2010; Azizi-Shotorkhoft et al. 2016). The selection criterium also considers the enzyme activity level for both cellulose and hemicellulose in which the levels need to be low. Hence, allowing more cellulose and hemicellulose to remain intact. This in turn allows rumen microbe to fully utilise the cellulose and the hemicellulose for the production of fatty acid (Hespell 1988). The differences between enzymes activity are not considered as the fungi were selected based on their average of total enzyme activity in the period of 15,30 , and 45 days for all enzyme tested. From previous research by Hassim et al. 2012, pre-treatment of OPF using white rot fungi shows increased in vitro ruminal degradability by $12 \%$. The fungi inoculum will be used to pre-treat OPF with incubation period of 45 days.

For the identification of fungi phylum, the fungi selected, the WR1, WR2, WR4, WR7, and WR10 are identified as basidiomycetes. It is due to the presence of clamp connection in hyphae of the fungi. It is correlates to the ability of basidiomycetes as an excellent degrader of lignin (Hatakka 1994).

Further research is needed to further identify the species of the fungi Species determination will allow more understanding on their full enzyme potential to enable more efficient pre-treatment of OPF via fungal extracellular enzyme.

\section{CONCLUSION}

By measuring the activity of laccase, lignin peroxidase, manganese peroxidase, avicelase, xylanase and carboxylmethylcellulase, it can be concluded that WR1, WR2, WR4, WR7, and WR10 are the best fungi for pre-treatment of oil palm fronds as animal feed, more specifically, ruminants. The selected fungi are identified as basidiomycetes from the presence of the clamp connection in the hyphae.

\section{REFERENCES}

Abdullah N, Sulaiman F. 2013. The oil palm wastes in Malaysia. Biomass Now - Sustainable Growth and Use. 3:75-100. doi: 10.5772/55302.

Alam MZ, Muhammad N, Mahmat ME. 2005. Production of cellulase from oil palm biomass as substrates by solid state conversion. Am J Appl Sci. 2:569-572. doi 10.3844/ajassp.2005.569.572.

Azizi-Shotorkhoft, Mohammadabadi T, Motamedi H, Chaji M, Fazaeli H. 2016. Isolation and identification of termite gut symbiotic bacteria with lignocellulosedegrading potential, and their effects on the nutritive value for ruminants of some by-products. J Anim Feed Sci Technol. 221:234-242. doi: 10.1016/j.anifeedsci. 2016.04.016
Binod P, Satyanagalakshmi K, Sindhu R, Janu KU, Sukumaran RK, Pandey A. 2012. Short duration microwave assisted pretreatment enhances the enzymatic saccharification and fermentable sugar yield from sugarcane bagasse. Renew Energy. 37:109-116. doi: 10.1016/j.renene.2011.06.007.

Dias AA, Freitas GS, Marques GSM, Sampaio A, Fraga IS, Rodrigues MaM, Bezerra RMF. 2010. Enzymatic saccharification of biologically pre-treated wheat straw with white-rot fungi. Bioresource Technol. 101:60456050. doi: 10.1016/j.biortech.2010.02.110.

Dinis MJ, Bezerra RMF, Nunes F, Dias Aa, Guedes CV, Ferreira LMM, Rodrigues MaM. 2009. Modification of wheat straw lignin by solid state fermentation with white-rot fungi. Bioresour Technol. 100:4829-4835. doi: 10.1016/j.biortech.2009.04.036

Gusakov aV, Sinitsyn aP, Klyosov aa. 1985. Kinetics of the enzymatic hydrolysis of cellulose: 1 . A mathematical model for a batch reactor process. Enzyme Microb Technol. 7:346-352. doi: 10.1016/0141-0229(85)901140 .

Hassim HA, Lourenço M, Goh YM, Baars JJP, Fievez V. 2012. Rumen degradation of oil palm fronds is improved through pre-digestion with white rot fungi but not through supplementation with yeast or enzymes. Can J Anim Sci. 92:79-87. doi: 10.4141/cjas2011-097.

Hatakka A. 1994. Lignin-modifying enzymes from selected white-rot fungi: Production and role from in lignin degradation. FEMS Microbiol Rev. 13:125-135. doi: 10.1111/j.1574-6976.1994.tb00039.x.

Haq, Khan IA, Butt WA, Ali S, Qadeer MA. 2002. Effect of carbon and nitrogen sources on Xylanase production by mutant strain of Aspergillus niger GCBMX-45. J Biol Sci. 2:143-144

Hespell RB. 1988. Microbial digestion of hemicelluloses in the rumen. Microbiol Sci. 5:362-365.

Moore KJ, Jung HJG. 2001. Lignin and fiber digestion. J Range Manag. 54:420-430. doi: 10.2307/4003113.

Namoolnoy P, Phoolphundh S, Wongwicharn A. 2011. Biodegradation of lignin in oil palm fronds by white rot fungi. Kasetsart J Nat Sci. 45:254-259.

Smith M, Thurnston CF. 1997. Fungal laccases: Role in delignification and possible industrial application. In: Messerschmidt A, editor. Multi-Copper Oxidases. Singapore, New Jersey, London, Hong Kong: World Scientific. p. 253-259.

Toda T, Strausbaugh Ca, Rodriguez-Carres M, Cubeta Ma. 2012. Characterization of a Basidiomycete fungus from stored sugar beet roots. Mycologia. 104:70-78. doi: $10.3852 / 10-416$.

Wan-Rosli WD, Law KN, Zainuddin Z, Asro R. 2007. Effect of pulping variables on the characteristics of oil-palm frond-fiber. Bioresour Technol. 93:233-240. 
Zahari MW, Farid MM. 2011. Oil-palm by-products as feeds for livestock in Malaysia. p. 1-21. [accessed July 21th 2016]. http://umkeprints.umk.edu.my/1147/1/Paper\% 202.pdf.
Zhang Z, Zhao ZK. 2010. Microwave-assisted conversion of lignocellulosic biomass into furans in ionic liquid. Bioresour Technol. 101:1111-1114. doi: 10.1016/j.biortech.2009.09.010 